\title{
P A Jungian Approach to Self-fragmentation of Twentieth Century in Orwell's Nineteen Eighty Four
}

\author{
Mozhdeh Alizadeh Shirazi (Corresponding Author) \\ Faculty of Modern Languages and Communication, Universiti Putra Malaysia \\ E-mail: mozhdeh.alizadeh@gmail.com \\ Wan Roselezam Wan Yahya \\ Faculty of Modern Languages and Communication, Universiti Putra Malaysia
}

Received: 01-06-2014

Accepted: 01-08-2014

Published: 01-11-2014

doi:10.7575/aiac.ijalel.v.3n.6p.224

URL: http://dx.doi.org/10.7575/aiac.ijalel.v.3n.6p.224

\begin{abstract}
The problematic life of modern human has always been a significant issue for many areas of study. In reaction to the absence of romantic values and the unity of the pre-modern world, Human being was afflicted with a sense of inner crises which is referred to as self-fragmentation. Fragmentation is one of the significant features of twentieth century when a mode of anxiety subjugated both art and society. In such an atmosphere many writers of the modern century attempted to reflect in their works of literature, what they had experienced in the real world. Orwell's Nineteen Eighty Four is one of the popular novels of Modern Era that describes a modern but fragmented society wherein the modern human's lack of self-integration is perceptible. By representing how the protagonists respond to the voices of their psyches through characterization and dreams, which is also of crucial significance in Jung's Analytical Psychology, Orwell explores the roots of modern human's urge for achieving a cohesive sense of self. Accordingly, this study, attempts to illustrate how modern human steps in the path of individuation and to what extent these efforts meet with success, if any. To achieve this goal, some terms and notions of Jungian Criticism such as archetypes and the process of individuation will be borrowed, and a particular focus will be held on dreams occurring in the course of the story. In addition, this paper would like to argue that the dystopian society portrayed in these novels is the offspring of a mere rationalism which prevents human from knowing the opposing forces working within as well as the forces functioning from without.
\end{abstract}

Keywords: individuation, archetypes, anima/animus, fragmentation of self

\section{Introduction}

The first decades of twentieth century is characterized by the emergence of a new tendency called modernism. Modernism is a tendency or perhaps a movement that impressed arts and culture of the twentieth century and was felt all around the world by other movements such as Cubism, Dadaism, Surrealism and Futurism. In all the arts touched by modernism, a sense of unity and harmony which was the most fundamental element of practice for decades was challenged in favour of abstraction and selfsubjectivity (Barry, 2002, pp. 81-83). Modern century has encompassed two world wars that transformed the harmonic nature of humankind to an open sense of doubt and alienation from a cohesive sense. According to Barry, the years in between World War I and World War II is the period of high modernism and lots of changes and challenges that are attributed to modernism happened in this period of time (2002, pp. 81-83).

Unlike the Victorian time, which was the age of heroic actions and chevaliers ending to victory, modern period is characterized by abstract themes and the protagonists who are doomed to failure. In this regard, we see the main characters of lots of modern novels around the world, who are enmeshed in an absurd circumstance. For instance, in modern novels such as Joyce's Portrait of a Lady (Brown, 1989), Conrad's Heart of Darkness (Brown, 1989) and Hedayat's Blind Owl (Mahmoodi, Pillai, \& M.M, 2012), the authors depict a technologically advanced but fragmented spheres wherein the human's soul is disordered and broken down. Indeed, in reaction to the absence of the romantic values and the unity of the pre-modern world, modern human moved toward his inner sense of individuality and embraced the disordered world of twentieth century.

The result of such subjectivity is felt in literature as well as other areas of art. In contemplating the social circumstances and the works of literature in twentieth century, one comes to the understanding that lots of them share some common features that lead the world of twentieth century to a mode of fragmentation. In this regard, Osborne states: "In ideological terms, modernism - Elster claims - opts for an ethos of fragmentation and the accompanying fallacy of assuming that because the world is fragmented then so should be the work of art" (Osborne, 2011, p. 188). 
In modern century, writers tended to employ a new mode of writing based on their real experimentation that is they were to portray in their works of literature, what they perceived in the real world (Stape, 1996, p. 32). During twentieth century, a new mental illness dominated the world. It started from the first decades and increased to the end of the century. This illness that is called Borderline Personality Disorder (BPD) is caused by a sense of disorder or fragmentation in patient's personality. These patients fail to set up a harmonious self as their patterns of mind are disjointed or to a degree fragmented (Fuchs, 2007, pp. 379-387). This illness pervaded the world during modern period as the outcome of modernity and affected not only the human lives but both art and society. Such a mental-disorder is what is referred to as fragmentation of human mind in modern works of literature (Schimmel, 2002, pp. 381-399). For instance, the main characters in many of modern fictions such Stephen in Joyce's Portrait of the Artist as a Young Man or Paul in Lawrence's Sons and Lovers to a degree lack a sense of cohesive thought (Brown, 1989, p. 36). The same story matches with the Orwell's protagonist in Nineteen Eighty Four that is published in the period of high modernism (Brown, 1989, pp. 18-19). Accordingly, this paper aims at focusing on the protagonists' mental conflicts in Orwell's Nineteen Eighty Four regarding the representation of self-fragmentation as one of the many outcomes of modern period. Moreover, since one of the major theories of the Jungian analytical school of psychology is the concept of individuation -human urge for self-integration-this study benefits from a Jungian approach for analyzing the extant of the protagonist's success in the path of achieving self-integration.

George Orwell is one of the significant figures of $20^{\text {th }}$ century English literature. He published Nineteen Eighty Four in 1949 as the aftermath of the World War II. The available literature on Nineteen Eighty Four shows that critics have studied these novels through several perspectives such as power, language, and psychoanalysis, but they failed to explore them through the lens of Jungian analytical psychology with regard to the concept of individuation. However, the significance of this study is not merely the application of the individuation process to a work of literature, but to seek for the reasons of the protagonist's sense of fragmented self.

Orwell's Nineteen Eighty Four that has been published just after the World War II in 1949, the heyday of modernism, is the story of a technologically advanced society where the protagonist suffer from a mode of anxiety. Through his novel, Orwell questioned to a degree the totalitarian regime of the Soviet Union and his own problematic life in Britain (Sawant, 2012; Varricchio, 1999, pp. 21-30). Influenced by the climate of war, Orwell drew the stretch of the totalitarianism to his novel Nineteen Eighty Four.

According to Morris, the dictatorial regime of totalitarianism that uses fear as a weapon to manipulate its people is well presented in Nineteen Eighty Four (Morris, 2012, pp. 15-19). In this respect, due to the dominant theme of Nineteen Eighty Four, and the social-political situation of Orwell's era, many critics have investigated this novel through the lens of totalitarianism. Gleason published his article of Totalitarianism in 1984, in the beginning of 1984 and states that although the nightmare of Nineteen Eighty Four never happened, we cannot reject what Orwell powerfully warned the world in 1949 (1984, pp. 146-159). In this regard, Nussbaum Gleason and Goldsmith also brought evidence to support the idea and state that Nineteen Eight Four is regarded as "one of the great exposes of the horrors of Stalinism" and consider Orwell, "the dramatizer of Cold War values" (2005, pp. 1-5).

Since human nature is highly influenced by his environment, a totalitarian regime can affect to a large extent the individuals' thought and behavior. That is to say by the raise of totalitarianism since World War II, the life of modern human has been in a serious danger. Discussing the issue, Gleason argues that no one can escape the extent of horror that totalitarianism brings to human life. In addition, the future generation may possibly experience the shock of totalitarianism within the boundaries of twentieth century when the "non-political" $(1984$, p. 159) private life of human has come to its end (1984, pp. 146-159). The sketch of totalitarianism is so prevailing in Nineteen Eighty Four that Greenwald, referring to the novel's ending, claims that protagonist's ultimate victory over himself and his loss of individuality proves that he is "the perfect citizen of the totalitarian society" (1980, p. 609).

However totalitarianism also overshadows the characters' inner issues. By depicting a protagonist who has lost his sense of individuality in a totalitarian society, Orwell has added a pessimistic tone to his novel making it an efficient source for those critics who works on pessimism. In his essay, Orwell's Political Pessimism, Lowenthal discusses Orwell's Objectives in explaining "the causes of the crisis of liberal civilization in the twentieth century" $(1969$, p. 161). On the other hand, Orwell according to Kateb, is to degree overstating in his pessimism toward the totalitarian society of Nineteen Eighty Four (1966, pp. 564-580). Perhaps the sad and pessimist tone employed by Orwell in Nineteen Eighty Four, make readers to suspect the whole story. Nevertheless there lies much in Nineteen Eighty Four close to reality and the reality is the problematic life of modern human within the totalitarian world of twentieth century (Kateb, 1966, pp. 564-580). Opposing to Kateb, Hensley believes that Orwell has reconstructed the world of his own in Nineteen Eighty Four. While exploring the sketch of dystopia in Nineteen Eighty Four, Hensley states:

In many dystopian novels, the anti-utopian society emerges from a world that closely resembles our own, or that of the author; one of the best examples of this is 1984 in which the society of Big Brother has evolved from a post-war world similar to the one in which Orwell lived when he wrote the novel. (2006, pp. 3-4)

Along with totalitarianism, critics are also keen to apply the concept of power to Nineteen Eighty Four. Tyner's article is a Foucauldian reading of Nineteen Eighty Four, through which he discusses the disciplinary discourse of the novel. Accordingly, he argues that the world portrayed by Orwell in the novel matches with the Foucauldian theory of power. That is to say individuality, humanity and knowledge are under the restricted authority of the power in Nineteen Eighty Four (Tyner, 2004, pp. 129-149). Such a constrained control of the ruling party on the society depicted by Orwell has created a mode of crisis throughout the novel. Indeed Nineteen Eighty Four with all its pessimistic impressions is the sub-product of the post-war periods. In this regard Resch indicates that, the post war circumstance of society as well as 
the satiric rules of the main power, has created a kind of dystopian society that is mainly the product of the brutality of the cold war (Azizmohammadi \& Saadatmanesh, 2013; 1997, pp. 137-176).

In the dystopian society rendered by Orwell, the protagonist alienates himself to from his surrounding to react against the brutality of war aftermath. In arguing the protagonist response to the totalitarianism Morris asserts:

In an attempt to remain "human" these individuals may reject the enforced codes of conduct, and become frustrated, hostile, aggressive and rebellious. Non-conforming behaviour of this nature is usually attributed to the psychologically disturbed and in all likelihood would not be tolerated by the governing institution. (2012, p. 16)

In the same line with Morris, Regis claims that Orwell has depicted a negative utopia through his novel. There is no doubt that the setting of Nineteen Eighty Four is a dystopian society because the human rights are ruined under the severe authority of a totalitarian government. But Regis considers such a society a negative utopia. It is utopia, because in the modern society depicted by Orwell, the technology and knowledge are in their advanced form; however it is negative because both knowledge and technology are under the dominance of to the government. For constructing such a negative utopia, a society should already have a certain capacity (Regis, 2013, pp. 109-115). Consequently Regis states:

Another important aspect is the fact that human beings cannot be simply dehumanized and brainwashed in order to follow rules and completely forget their own human nature of love and care. It would need years of analysis and studies to find a way of diminishing one's individuality as well as psychological and physical observations. That requires technology and money, and indeed, in Orwell's world, this was completely feasible. (Regis, 2013, pp. 114-115)

Orwell portrays through his novel the horrors of modern life that are intensified after the World War II. Such a depiction of the modern society drew the attention of the critics to a much more interior question, regarding human nature, than totalitarianism and power. In this respect they have also applied concepts other than socio-political issues to Nineteen Eighty Four. For instance, Ashipu and Okpiliya focus on the humans' oppression and its reflection on the sort of language they use in Nineteen Eighty Four. A mode of oppression according to Ashipu and Okpiliya has been created through the novel in a society that is crushed by the "unjust use of force, victimisation, dehumanisation, demonization, authority or society norms" (2013, p. 78). Such a dull circumstance is transformed from the human nature to his language since there is a close relation between language and the sense of self perception. Because the human sense of self is crushed, so do the language (Ashipu and Okpiliya, 2013, pp. 78-82).

Narrowing his lens to the inner world of the characters, Rozen investigates the psychological issues in Nineteen Eighty Four. Nineteen Eighty Four has been written in the period of Cold War when the intellectual were keen to focus on individual's psychology. In discussing the novel on the basis of the Freudian theory, Rozen seeks for the similarities between Freud and Orwell. Focusing on the parallels between them, He argues that with all their differences, Orwell and Freud are "surprisingly similar"(1978, p. 296). However, despite that the individuals' psychological problems are rooted in the nature of modern century, a few psychologies have been explored this great novel of the era regarding the psychological issue. Although a critic like Rozen has occupied a psychoanalytic approach to Nineteen Eighty Four, other psychoanalytic approaches such as the Jungian theory of analytical psychology have never been applied to this very popular novel of twentieth century. In this respect, given the significance as well as the importance of modern human in the literary researches, there is still a need for farther knowledge about the psychological problems of modern human.

\section{Method}

The present chapter is an in-depth analysis of Nineteen Eighty Four by George Orwell based on the Jungian notion of individuation and also with regard to the effect of self fragmentation of modern century on literature. Moreover, Due to the writer's focus on the protagonist's dreams as well as their significance in illuminating the process of individuation, the protagonist's journey of reaching wholeness will be traced through the dream analysis based on the Jungian assumption of 'dreams'. In this regard since the mentioned concepts are of high significance in the analysis of the study, a clear understanding of them seems necessary.

\subsection{Literary Modernism and Fragmentary Self}

The notion of self-fragmentation emerged initially in the twentieth century when the uncertainty of modernity coincided with the sense of self-complexity evolved in the nature of modern humankind. Such an issue made the psychologists cast an eye on the process during which human self challenges the features of the modern century. A number of studies have so far been accomplished on the concept of self-fragmentation by psychologists that are really assistive in posing a brighter understanding of the topic. According to a study by the psychologist Fusch, a new mental-illness dominated the world during twentieth century. It started from the first decades and increased to the end of the century. This illness that is called Borderline Personality Disorder (BPD) is caused by a sense of disorder or fragmentation in patient's personality. Defining the illness, Fusch states:

Patients with BPD lack the strength to establish a coherent self-concept... This results in a temporal splitting of the self...Thus, borderline individuals exhibit what may be called a fragmentation of the narrative self...or the fragmentation of identity (2007, p. 380)

BPD as the consequence of modern period touched the individuals who suffered from a sense of nervousness which made them perform disordered behaviours. Janis, Veague and Driver-Linn, contribute such behaviors to a sort of selfdisorder in these patients and explored different theories that examined the tribulations of human self. One of the prevailing theories of self-disorder is Westen and Cohen's that contributes the lack of a cohesive sense of self to these patients and labels the phenomena as the fragmentation of self. Individuals with fragmented selves fail to make 
stabilized decisions and to have coherent thoughts. Ultimately, such a phenomena expose them deep to the troubled interpersonal relationships (Janis, Veague, \& Driver-Linn, 2006, p. 388).

Many of literary works published during the war are devoted to the atmosphere of war and the dominant social mess of that time. Among these writers is Georg Orwell who cares much about the sort of damage that war brought to human psyche. In his essay, Incarceration and Torture, Gutierrez refers to the setting of Nineteen Eighty Four as an unendurable to a degree that a sense of individual independent self may subject to harsh dangers(1984, pp. 4-19).

\subsection{Individuation}

Individuation is the goal of Jungian analytical psychology which is the process through an individual can achieve and integrated inseparable personality(Gibb, 2012, pp. 67-74). In his The Archetype and The collective Unconscious, Jung claims: "I use the term "individuation" to denote the process by which a person becomes a psychological "in-dividual, "that is, a separate, indivisible unity or "whole" (C. G. Jung, 1959, p. 275). That is to say, in order to accomplish the process of 'individuation', one should make a balance between the conscious and unconscious elements of the psyche.

\subsection{Conscious/Unconscious}

According to Jung, man's psyche is divided into three phases: 'Consciousness', 'Personal Unconscious' and 'Collective unconscious'(C. G. Jung, 1959, pp. 1-5). Consciousness is the part of mind which controls our conscious behaviour and is the realm of ego. In contrast, Unconscious is the deep structure of psyche that is divided into two parts: personal and collective. Personal unconscious is the personal part of unconscious, which belongs to you individually. It contains subliminal discernments or repressed feelings and wishes that Jung defines as Complexes. This layer of unconscious mind lies upon a deeper layer that is Collective unconscious. Collective unconscious is an inborn acquisition, which is not derive from personal experience but is a universal entity and contains modes of behaviour and is identical of all individuals(Chang et al., 2013, pp. 205-214). These modes and components which Jung calls 'archetypes', are capable of being present in conscious behaviour (C. G. Jung, 1959, pp. 1-5).

\subsection{Anima}

Among the archetypes of collective unconscious, 'anima' is of crucial importance. Anima is the feminine soul in the psyche of the man. It is the personifications of all female tendencies in men which can be appear as a goddess or a witch (C. G. Jung, 1971, pp. 450-499; Meredith-Owen, 2012, pp. 167-186). It is also regarded by Jung as the projection making element in the soul of a man. In this respect he indicates:

The projection-making factor is the anima, or rather the unconscious as represented by the anima. Whenever she appears, in dreams, visions, and fantasies, she takes on personified form, thus demonstrating that the factor she embodies possesses all the outstanding characteristics of a feminine being. She is not an invention of the conscious, but a spontaneous product of the unconscious. (1951, pp. 13-14)

\subsection{Self}

Self in the Jungian analytical psychology indicates the integration of conscious and unconscious parts of the psyche. For many, the concept of self is analogous to the ego, however Jung argues that it not only corresponds with ego but also "includes it"(C. G. Jung, 1959, p. 142). Self is the totality centre of the psyche which is so significant in Jungian theory to the extent that Jung refers to self as the goal if Individuation process.

\subsection{Dream}

Individuation is the main concern of Jung, and the first step toward individuation is becoming aware of the unconscious world. In this process, dreams are the hints or guidelines toward the unconscious world. In The Practice of Psychotherapy, Jung regards dreams as a product of the psyche and asserts that: "to know and understand the psychic life-process of an individual's whole personality, it is important to realize that his dreams and their symbolic images have a much more important role to play" (C. G. Jung, 1968, p. 12). Accordingly Jung adds:

The general function of dreams is to try to restore our psychological balance by producing dream material that re-establishes, in a subtle way, the total psychic equilibrium. This is what I call the complementary (or compensatory) role of dreams in our psychic make-up.(1968, p. 34)

\section{Discussion}

Orwell's Nineteen Eighty Four is misunderstood if not considered in its contemporary environment when it is written as Orwell's writing has always embraced the elements of truth he witnessed around him. Known as a political writer, Orwell states in his essay, Why I Write:

I give all this background information because I do not think one can assess a writer's motives without knowing something of his early development. His subject matter will be determined by the age he lives in --at least this is true in tumultuous, revolutionary ages like our own --but before he ever begins to write he will have acquired an emotional attitude from which he will never completely escape. $(1954$, p. 1)

As a modern experimental writer, Orwell tends to mirror in his text what he has experienced in the real world. The setting of Nineteen Eighty Four is London 1984 to say that such a society may happen to exist here in the post war situation when War economically had broken England effectively. That is to say, it is of high importance to regard the crisis of Orwell's contemporary era such as famine, shortage and oppression, as his powerful motivation in writing Nineteen Eighty Four(Quinn, 2009, pp. 232-260).

By writing this book Orwell is trying to warn people of the risks of what occurs if the revolution is tricked. In this regard, Nineteen Eighty Four was intended to say how the protagonist, the representative of every human, is trapped in a modern society which is ruled by the power of totalitarianism. The text raised a question: can a human being withstand the power of the modern era (Rodden, 2007, p. 9)?

The protagonist, Winston Smith, is a member the Outer Party — a low-ranking party — who lives in London that is a city in the state of Oceania. Oceania is a technologically advanced society that rules the people by the aid of the power of 
modern technology. People of Oceania live under the restrict authority of the government. They are watched and regulated by CCTVs called telescreens making impossible, every single movement done out of the government's sight. Even the individual's thoughts have to be in line with government's targets. Although Winston feels the restricted rules of the Party, he is afraid of moving beyond the boundaries that the government has imposed on him otherwise he will be doomed to a horrifying end in the Ministry of Love that ironically is the most dreadful place one can imagine to stay. The Leader of the state is Big Brother whose commands are executed by his representative, O'Brien who is one of the members of the inner party. Yet, despite such a confined circumstance, Winston starts to write a diary and falls in love with Julia, both of which are considered as serious crimes. Indeed these oppositions against the government can be considered as his first major moves toward reclaiming his individual subjectivity.

\subsection{Approaching the Unconscious}

The first step toward the process of individuation is to become aware of the hidden world of the unconscious. Jung has divided the sum of the unconscious part of psyche to the 'personal' and the 'collective'. While personal unconscious is a part of psyche that embraces the repressed personal feeling of the individual, the collective unconscious is the deeper layer which deals mainly with the whole experience of the humankind during the history. In order to achieve an integrated self, an individual should make a balance between these unconscious parts of the psyche and the consciousness. Once individuals initiate the task of the psychic growth, they have to ponder the guiding signals they receive from "the totality of the psyche"(Von Franz, 1968, p. 167), that is the Self. However, the real journey of individuation starts when someone is seriously offended or suffered from a sense of tediousness in the life. However, everything may seem to be right but they are all in the surface as the person is suffering from some boredom deep within the psyche. This is the very state that causes an individual to deal with exploring the world within (Von Franz, 1968, pp. 169-170).

Orwell starts Nineteen Eight Four with the gloomy scene of Winston's arriving at his apartment:

"It was a bright cold day in April, and the clocks were striking thirteen (Orwell, 1949, p. 1)."This is the very first sentence of the novel which implies the tedium of Winston's life. By employing the words "cold", "April" and "thirteen", Orwell emphasises on the sad tone prevailing on the novel. In this regard, the coldness of a day in April resembles the cold and sad circumstance that is dominant on the protagonist's society. It seems that while in writing the opening sentence of Nineteen Eighty Four, Orwell was influenced by T. S. Eliot.

Among the pioneers of modernism, T. S. Eliot is highly appreciated by George Orwell. The influence of Eliot on Orwell was so high that according to Stewart, Orwell has written Nineteen Eighty Four, in response to Eliot's The Waste Land (Stewart, 1981, pp. 150-152). "April" according to what Eliot in his The Waste Land, is: “...the cruellest month/ Lilacs out of the dead land, mixing /Memory and desire, stirring / Dull roots with spring rain (1-4)".

In these lines by Eliot, April is paradoxically portrayed as a cruel season wherein the memory of the good past mixed with the vague future to show how modern life has missed its traditional basis (Brooker, 1992, pp. 61-63; Ferber, 1999, p. 14). What seems obvious about both Nineteen Eighty Four and The Waste Land -is that, both of them complains about the unchangeable societies of modernism for the sake of their good past (Stewart, 1981, pp. 150-152). Perhaps George Orwell, just like Eliot in The Waste Land, begins Nineteen Eighty Four with April to emphasis on the similarities between his society and Eliot's. That is to say both of these works are portraying the modern society wherein is no hope of change (Stewart, 1981, pp. 150-152).

The next part of the opening sentence is "the clock's striking". The clocks are striking thirteen. The question is that, why Orwell has used the number thirteen and not for instance fourteen or any other numbers? According to Cirlot's dictionary of symbols, "thirteen" is a number with an unfavourable connotation which is the symbol of "death and birth" (1962, p. 234). It seems that there may lay an intention behind employing this number together with the tone of the clock's striking. The clocks are normally used to remind something. Since the number thirteen is the symbol of death and birth, the clocks are striking thirteen to remind Winston of some change that have to be happened. Possibly, Orwell tries to express that something, perhaps some life, has to die in order to give birth to a new life. Yet the unfavourable implication of the number thirteen adds more anxiety to the boring scene that Orwell has described in portraying Winston's life at the beginning of the novel.

Generally speaking, the sentence, "It was a bright cold day in April, and the clocks were striking thirteen (Orwell,1949, p. 1)" implies that a gloomy tone is dominant in the Winston's society and a need for a change, a sort of death and birth, is felt in the Winston's life. The smell of "boiled cabbage (Orwell, 1949, p. 1)" and "old rag mats (Orwell, 1949, p. 1)", "the electric current (Orwell, 1949, p. 1)" which is "cut off during day light (Orwell, 1949, p.1)" and the "lifts (Orwell, 1949 , p. 1)" that are working are the evidences to show everything is in decay. This boring state wherein Winston is suffering from his tedious monotonous life can be the very state wherein and individual becomes attentive to the existence of some secret world within. Wounded in such a dull situation, Winston starts to write a diary which is his first serious move against the party. "The thing that he was about to do was to open a diary. This was not illegal (nothing was illegal, since there were no longer any laws), but if detected it was reasonably certain that it would be punished by death..." (Orwell, 1949, p. 3)

Diary writing is a very personal event and everyone has an inalienable right to write his memoirs. However, even this very personal right has been taken from the people of Oceania. Although Winston knows that diary writing may be terminated at his death, he is so motivated to write about himself that nothing will stop him. Indeed by starting the diary, Winston expresses his interest toward discovering the inner self.

In Jungian analytical psychology, the first step of individuation process is referred to as the state of self-realization (C. G. Jung, 1954, pp. 172-186). In this regard, Winston starts writing his memoir to identify himself. In his first writing attempt, he is not well informed of what he is writing. His internal feeling is too suppressed that he bursts into writing 
freely, without any accurate understanding of it which shows he is at the gate of the unconscious world. "He was conscious of nothing except the blankness of the page in front of him, the itching of the skin above his ankle, the blaring of the music, and a slight booziness caused by the gin"(Orwell, 1949, p. 4).

The important thing is that Winston is at the beginning of approaching his unconscious world within. His tiresome life, just like a shock, has thrown him into his unconscious and writing diary is a good evidence for showing to what extent he is eager to discover the hidden layers of his psyche.

\subsection{Anima/Animus}

Gradually Winston cares more about his inner desires. He commits a more serious crime and falls in love with Julia who matches well, with the Jungian concept of anima.According to Jung, anima is the feminine soul of a male body that "is usually projected upon women" (C. G. Jung, 1959, p. 27). It is also because the existence of anima that a man suddenly falls in love with a woman whom he sees for the first time (Von Franz, 1968, p. 191). Generally speaking, anima which seems to appear initially through the 'mother figure' is the main projection-making factor of the male unconscious psyche. However anima is not only identical to the mother figure, but also to the images of "the daughter, the sister, the beloved, the heavenly goddess, and the chthonic Baubo" (C.G. Jung, 1951, pp. 9-13).

While writing his diary, Winston comes to understanding that his main reason for starting diary has been his first encounter with Julia. Winton begins the criminal act of writing the diary in the same day he sees Julia - a dark haired girl-- for the first time. "It was, he now realized, because of this other incident that he had suddenly decided to come home and begin the diary today (Orwell 4)".

When Winston reminds of Julia, he refers to the 'dark-haired girl'. The word, 'dark', may remind the reader of some correspondence between Julia and the dark part of the psyche. In the procedure of self-realization, Julia plays the role of Winston's first motivator to rebel against the community which has banned whatever connection between the party members and their personal inner self. In this regard, Julia corresponds with the Jungian concept of anima since she is a 'mediator', who connects Winston to his unconscious world.

This idea is in the same line with that of von Franz, a major Jungian psychologist, who asserts: "the anima takes on the role of guide, or mediator, to the world within and to the Self" (1968, p. 193).

However, Winston's first contact with Julia provoked a sense of hostility in him. Winston sees Julia initially in the Two Minutes Hate, a period during which the members of the party are shown a film about the party opponents and they have to express their hatred toward the party enemies. Nevertheless, instead of the Big Brother's enemy, Winston expresses his hate toward Julia.

Winston succeeded in transferring his hatred from the face on the screen to the dark-haired girl behind him... He would ravish her and cut her throat at the moment of climax. Better than before, moreover, he realized why it was that he hated her. He hated her because she was young and pretty and sexless, because he wanted to go to bed with her and would never do so... (Orwell, 1949, p. 7)

Winston is expected to insult Big Brother's opponents during the Tow Minutes Hate. However, while all the 'comrades' are shouting their swear words to the party enemies, a different story happens in Winston's mind. Winston 'succeeded to transfer his hatred' to Julia. Obviously, Winston desires to have such a 'pretty girl' beside him but he cannot, because he is not allowed to. He desires Julia, but paradoxically he 'projects' his hatred toward her to take his revenge on her. This scene shows that Winston is trying to differentiate himself from the party members, since he intentionally moves his feelings and thoughts away from the others'. Orwell has employed the world 'succeed', when he refers to the scene that Winston 'transfers' the direction of his hatred from the enemies to Julia. Even the use of the word 'succeed' implies that there lies a sense of personal intention and not accident behind 'transferring the hatred'. Winston is not only succeeded in transferring his thought from 'the face on the screen' to Julia, but also he is succeeded to claim his uniqueness by detaching himself from the party members. Accordingly Julia seems to correspond with Winston's archetype of anima.

Although the main motivator of Winston's claims for his inner self is Julia who is appeared repeatedly in both his dreams and his real life, it should not be ignored that all the contents of anima is not revealed through the projection . Anima can also appear in dreams and fantasies. For instances in some Winston's dreams, anima emerges through the characters of his mother and his sister. That is obviously why the dreams play an undeniable role in attaching an individual to the unconscious world within.

\subsection{Dream Analysis}

Perhaps the significance of dreams in the Jungian analytical psychology is irrefutable. The contents of the human unconscious psyche find way to the conscious world through dreams however as symbolic images that is to say dream images appear not accidentally but to send the signals of unconscious to the conscious part of human psyche (C. G. Jung, 1968, pp. 1-11). Due to the guiding role of dreams in the process of individuation as well as Orwell's special focus on a series of Winston's classified dreams throughout the story, this study will follow the protagonist's dream as messages of the unconscious world.

Winston starts to remind his dreams at the very beginning of his diary. The first dreams he remembers, goes back to seven years ago.

...he was walking through a pitch-dark room. And someone sitting to one side of him had said as he passed: 'We shall meet in the place where there is no darkness. It was said very quietly, almost casually-a statement, not a command. He had walked on without pausing. What was curious was that at the time, in the 
dream, the words had not made much impression on him. It was only later and by degrees that they had seemed to take on significance. (Orwell, 1949, p. 12)

Darkness in dreams corresponds with the archetype of shadow and generally the dark side of human mind that is the hidden unconscious world within. Since a great deal of the psyche is unfolded for human beings, Jung attributes the darkness to the world of unconscious (C. G. Jung, 1968, pp. 3-94).

Starting from that the darkness corresponds with Winston's unconscious psyche, the phrase he hears in his dream; "the place where there is no darkness" (Orwell, 1949, p.12), refers to a place where there is no dark point in Winston's unconscious and a time when all the components of the hidden world of his psyche is uncovered.

Since Winston's dream belongs to his past when he did not care much about his unconscious, what he hears in his dream has no effect on him on that time. Presumably that is why he walks without any' pause' as if he hears nothing. However, in the present time when Winston has taken his first steps in the process of individuation, the statement seems to share some meaning with him. Perhaps the voice Winston perceives intensifies the idea that he is receiving a message from his unconscious, telling him that you will be aware of the existence of the unconscious world when the true nature of your hidden world within is going to be revealed in a 'place where there is no darkness'.

Recalling his dream, Winston comes to the understanding that he is gaining a new meaning from the dream which is different from what he thought before. He assures that he is committing a 'thought crime' and his life is going to enter to a new phase. Although he knows well that the people who commit the thought crime will doom to death, his insuppressible urge for writing the diary does not lessen but rather he clings more on discovering the unknown meanings of his life.

Winston's second dream happens soon after he realizes that to what extent he is keen to find the secrets of his unconscious world. The dream happens in two different phases. Initially Winston dreams the death of his mother and his sister. In his dream, Winston sees that: "They were down in some subterranean place--the bottom of a well, for instance, or a very deep grave--but it was a place which, already far below him, was itself moving downwards" (Orwell, 1949, p. 14).

Since "the character of a man's anima is as a rule shaped by his mother"(Von Franz, 1968, p. 193), the mother figure in Winston's dream is corresponding to his anima. The significant point here is the setting of the dream that is a subterranean place which refers to the deep layers of the hidden psyche.

In the dream the mother figure holding the hand of Winston's sister, was "in the saloon of a sinking ship, looking up at him through the darkening water (Orwell, 1949, p. 14)" and Winston was standing somewhere in light. What is implied in this scene is that Winston's anima is sinking in some dark place that is the unconscious world and Winston is standing in the light world of the consciousness. It seems that their sinking has made no impression on Winston as he stands there watching their sinking with no efficient move to save them. They do not blame Winston for not saving them because "they must die in order that he might remain alive" (Orwell, 1949, p. 14). In other words, if Winston wants to live his ordinary life in the modern world of Oceania, he has to ignore the existence of his inner world with all its components. Winston has to care only about his conscious mind while ignoring his inner self and the image of his anima letting her sink in the dark unconscious part of his mind.

Just after the mother's sinking, the scene changes from a dark sinking ship to a light landscape. Winston is in a light countryside that he called, "Golden country" and sees a dark hair-girl who tears off her clothes running toward him provoking the idea of Winston's urge for sexuality. However, "it aroused no desire in him; indeed he barely looked at it. What overwhelmed him in that instant was admiration for the gesture with which she had thrown her clothes aside" (Orwell, 1949, p. 14). In this scene, what amazed Winston is not merely sexuality, but the way the 'dark-haired girl' tears her clothes off. Considering that the girl is Winston anima, her body is not what he cares for but the way she tears her clothes off. Symbolically, the dark-haired girl is a messenger who comes from the unconscious world to uncover the facts that has been so far hidden for Winston. The whole trend of the dream implies that although in the first phase Winston tries to ignore the existence of the dark side of his mind, he shows his wish of discovering the unconscious when the scene suddenly changes to the 'Golden Country'.

At this point in the story Winston becomes attentive to start his journey of individuation since he has been aware of his unconscious world within. The evidence for this claim is that soon after the dream Winston has projected what he has seen in the dream to his real life. Just after the dream he sees Julia — a dark-haired girl—and plans to sleep with her in a room is the country side which is analogues to the scene of the 'Golden Country'. It shows that to what extent Winston is eager to follow the message of his unconscious as he brings his anima from a dream to the real world.

Although Winston starts his journey of individuation intentionally, it cannot be ignored that it is Julia-the animawho guides him through the path of individuation. Accordingly, once they plan to sleep with each other Winston believes that Julia can be "trusted to find a safe place". Generally speaking it is Julia who gives Winston the address and teaches him how to find the room in the countryside, that is to say Julia plays the role of Winston's anima in showing him how to pass the conventions of the conscious world.

Winston's relationship with Julia strengthens and they visit each other frequently. In one of the times they are sleeping with each other, an issue makes Winston to remember a nightmare that has repeatedly been occurred during his life. They saw a rat in the room and in a conversation with Julia he confesses shamefully to his fear of rats. "Dearest! You've gone quite pale. What's the matter? Do they make you feel sick'? 'Of all horrors in the world - a rat" (Orwell, 1949, p. 68)! Winston feels "ashamed of himself" (Orwell, 1949, p. 69) as his fear of rats is seemingly his Achilles heel. Rat is the very entity in the world of which he is afraid to death. Since the archetype of shadow refers to those 
characteristics of humans' personality that they are ashamed of (C. G. Jung, 1953, p. 166), Winston's fear of rat, to degree resembles his archetype of shadow.

Just after his confession to the fear of rats, Winston reminds of his nightmare:

He was standing in front of a wall of darkness, and on the other side of it there was something unendurable, something too dreadful to be faced. In the dream his deepest feeling was always one of selfdeception, because he did in fact know what was behind the wall of darkness. With a deadly effort, like wrenching a piece out of his own brain, he could even have dragged the thing into the open. He always woke up without discovering what it was. (Orwell, 1949, p. 68)

The nightmare foreshadows the possibility of the existence of a barrier in front of Winston's individuation process. A 'wall of darkness' is in front of him and behind that is the most dreadful entity that one can face with. This is the very obstacle that Winston with which himself is afraid of confronting. Winston refers the nightmare to what Julia says about the rats: "don't worry, dear, we're not going to have the filthy brutes in here. I'll stuff the hole with a bit of sacking before we go. And next time we come here I'll bring some plaster and bung it up properly" (Orwell, 1949, p. 83). Presumably, Winston's connecting his nightmare to Julia's words about the rats provokes the idea that there lies some connections between the rats and the dreadful entity behind the wall in the Winston's nightmare.

According to the Hall and Clark's Dictionary of Symbols, rat symbolizes the destruction and decay (1979, p. 161). It is also the symbol of devil (Cirlot, 1962, p. 271). In this regard it is more likely that the rat is Winston's archetype of shadow. Rat is a devil figure in Winston's life that can possibly lead him to a sense of destruction. Winston's nightmare is a significant point in the story in that; it foreshadows his confrontation with the archetype of shadow.

The more Winston steps forward in the path of individuation the more he receives the unconscious messages through his dream. Winston's next dream occurred again while he is with Julia. His dream is a mixture of a dream and a memory:

The dream had also been comprehended by — indeed, in some sense it had consisted in — a gesture of the arm made by his mother, and made again thirty years later by the Jewish woman he had seen on the news film, trying to shelter the small boy from the bullets, before the helicopter blew them both to pieces. (Orwell, 1949, p. 76)

This is Winston's fourth dream since he has started his journey of individuation. Indeed, the dream is another message from the world within reminding that Winston is still in the way forward to individuation. The archetype of anima which in this dream switches to the image of Winston's mother represents his supporter. She shows a gesture of arms as if she is preventing him from blowing to pieces. This reinforces the role of anima in establishing a unity between different elements of the psyche. The anima is trying to assure Winston that she is supporting him in the way toward individuation avoiding a sense of self-fragmentation.

From this point in the story, everything goes well for Winston and Julia. They have rent a secret room where there is no tele-screen for their affair. They keep on going there until they understood that in spite of all precautions they take, the owner of the room has betrayed them and the police arrests Winston. These are the stream of the events that has happened in the surface. Symbolically speaking, Winston keeps on cooperating with his anima until the border between conscious and unconscious removes. The rational modern world wherein Winston lives consciously, comes to interact with the hidden world of Winston's unconscious. Both conscious and unconscious components of Winston's psyche meet each other and it is Winston who has to try for accomplishing his integrated self by making a balance between these opposing forces.

Winston is asserted and imprisoned in the Ministry of Love. He is interrogated by O'Brien who is the successor of Big Brother. In Nineteen Eighty Four, the reader does not face directly with Big Brother. Since commands of the party are executed through O'Brien, he is the personification of the party and the authorship. He is also the representative of the modern world wherein Winston lives. Indeed the Ministry of Love is the ground field for Winston's conflict with the modern conscious world and the inner components of his unconscious.

In the Ministry of Love Winston dreams "a great deal ... and they were always happy dreams" (Orwell 132): "He was in the Golden Country, or he was sitting among enormous glorious, sunlit ruins, with his mother, with Julia, with O'Brien--not doing anything, merely sitting in the sun, talking of peaceful things" (Orwell, 1949, p. 132).

The dream shows that all the components of Winston's psyche have been discovered. Julia who is the representative for Winston's unconscious comes to border with O'Brien who is the symbol of Weston's rational world of consciousness. They are challenging in the 'Golden Country', 'a place where in is no darkness', for the sake of achieving a total integrated self.

\subsection{End of the Journey}

While challenging with Winston in the Ministry of Love, O'Brien set him to 'the worst thing in the world':

The worst thing in the world,' said O'Brien, 'varies from individual to individual. It may be burial alive, or death by fire, or by drowning, or by impalement, or fifty other deaths. There are cases where it is some quite trivial thing, not even fatal'... In your case, said O'Brien, 'the worst thing in the world happens to be rats. (Orwell, 1949, p. 136)

In the process of individuation, modern rationality has always been a barrier. The rational nature of modern human does not let him imagine anything "that cannot be explained by the common sense"(C. G. Jung, 1968, p. 31). In his longlasting discussion with Winston, O’Brien who is the symbol of rational modern world does not let Winston believe in his unconscious world. He hits Winston where it hurts by setting him to his shadow. The shadow, as also is asserted by 
O'Brien, is different form an individual to another. For Winston, it is the rats. O'Brien reminds him of his dream in which he was in front of a wall and he did not dare to search behind it. He tells Winston that: "It was the rats that were on the other side of the wall" (Orwell, 1949, p. 165). O'Brien starts to fix a cage-like mask which was full of rats, on Winton's head. It is in this very moment that Winston gives up the conflict and betrays his anima by shouting: "Do it to Julia! Do it to Julia! Not me! Julia" (Orwell, 1949, p. 166)!

\section{Conclusion}

The fragmentation of inner self is the prevailing mode of modern century. This mode of being disordered has also been reflected in the literary works of the modern era. Nineteen Eighty Four is the story of a modern human who is entrapped within a fragmented circumstance of a technologically advanced society. In order to achieve a sense of unity the protagonist starts the journey of individuation which is the process of settling a balance between the conscious and unconscious parts of the human psyche. However in tackling the borders of the unconscious world, modern rationality is the main obstacle that a modern human being confronts. The panics that are rooted in the nature of modern civilization are much more frightening than the mythic devil of the primitive humans (C. G. Jung, 1968, pp. 31-37). It is these terrors that prevent modern human from opening his eyes to the spiritual nature of the psyche that is the unconscious world within.

Accordingly, although Orwell's protagonist is attentive to his unconscious world and starts the process of individuation, he betrays his anima as his conscious mind does not dare to face with the archetype of shadow. The protagonist's rationality forces him to remain faithful to the rules of the conscious world at the price of his failure in the path of individuation.

\section{References}

Azizmohammadi, F., \& Saadatmanesh, S. (2013). Analysis of Lexical Adjustment in two persian translations of George Orwell's" Nineteen Eighty-Four. Journal of Science and today's world, 2(6), 726731.

Barry, P. (2002). Beginning theory : an introduction to literary and cultural theory (pp. 81). Manchester [u.a.]: Manchester University Press.

Brooker, J. S. (1992). Reading The Waste Land: Modernism and the limits of interpretation: Univ of Massachusetts Press.

Brown, D. (1989). The Modernist self in twentieth-century English literature : a study in self-fragmentation. Basingstoke: GB : Macmillan press.

Chang, H.-M., Ivonin, L., Diaz, M., Catala, A., Chen, W., \& Rauterberg, M. (2013). Experience the World with Archetypal Symbols: A New Form of Aesthetics. Distributed, Ambient, and Pervasive Interactions, 205-214.

Cirlot, J. E. (1962). A Dictionary of Symbols, trans. Jack Sage (New York: Philosophical Library, 1962), 201.

Ferber, M. (1999). A dictionary of literary symbols: Cambridge University Press Cambridge.

Fuchs, T. (2007). Fragmented Selves: Temporality and Identity in Borderline Personality Disorder. Psychopathology, 40(6), 379-387.

Gibb, M. (2012). The Call to Individuation Reflections on Learning, Life and Work (pp. 67-74): Springer.

Gleason, A. (1984). " Totalitarianism" in 1984. Russian Review, 43(2), 145-159.

Greenwald, A. G. (1980). The totalitarian ego: Fabrication and revision of personal history. American Psychologist, 35(7), 603. doi: 10.1037/0003-066x.35.7.603

Gutierrez, D. (1984). Incarceration and Torture: The Self in Extremity. Human Rights Quarterly, 6(3), 284308. doi: $10.2307 / 762003$

Hall, J., \& Clark, K. (Eds.). (1979). Dictionary of subjects and symbols in art: Harper \& Row New York.

Hensley, M. (2006). The Green World of Dystopian Fiction, Diss: Western Kentucky University.

Janis, I. B., Veague, H. B., \& Driver-Linn, E. (2006). Possible selves and borderline personality disorder. Journal of Clinical Psychology, 62(3), 387-394. doi: 10.1002/jclp.20230

Jung, C. G. (1951). Aion. London: Routledge \& Kegan Paul.

Jung, C. G. (1953). Two essays on analytical psychology. New York: Pantheon Books for Bollingen Foundation.

Jung, C. G. (1954). The development of personality (R. F. C. Hull, Trans.). Princeton, N.J.: Princeton University Press.

Jung, C. G. (1959). The archetypes and The collective unconscious (R. F. C. Hull, Trans.). Princeton, N.J.: Princeton University Press.

Jung, C. G. (1968). Approaching The Uncoscious. In C. G. Jung, M. L. Von Franz, J. Jacobi \& A. Jaffe (Eds.), Man and His symbols. New York: Dell Pub.

Jung, C. G. (1971). Psychological Types (H. G. Baynes, Trans. Vol. 6). London; Princeton, N.J.: Routledge and K. Paul : Princeton University Press.

Kateb, G. (1966). The Road to 1984. Political Science Quarterly, 81(4), 564-580.

Lowenthal, D. (1969). Orwell's Political Pessimism in '1984'. Polity, 2(2), 160-175.

Mahmoodi, K., Pillai, S., \& M.M, R. (2012). Historical Hegemony: Fractured Identity and Monovocalization in Sadegh Hedayat's Blind Owl. Akademika, 82(2), 45-54. 
Meredith-Owen, W. (2012). The hero, the anima and the claustrum: anality and idealization. Journal of Analytical Psychology, 57(2), 167-186. doi: 10.1111/j.1468-5922.2011.01960.x

Morris, G. B. (2012). Human Behavior in an Emerging Totalitarian Society. Canadian Journal of Counselling and Psychotherapy/Revue canadienne de counseling et de psychothérapie, 11(1).

Nussbaum, M. C., Gleason, A., \& Goldsmith, J. (2005). On Nineteen eighty-four : Orwell and our future. Princeton, N.J.: Princeton University Press.

Orwell, G. (1949). Nineteen Eighty-Four. Fairfield (IA): 1st World Library - Literary Society.

Orwell, G. (1954). Why I Write. 1947. A Collection of Essays by George Orwell, 313-320.

Osborne, T. (2011). Rationality, choice and modernism: Notes on Jon Elster's theory of creativity. Rationality and Society, 23(2), 175-197. doi: 10.1177/1043463111404672

Quinn, E. (2009). Critical Companion to George Orwell: Infobase Publishing.

Regis, H. F. (2013). 1984 GEORGE ORWELL. Revista Letras Raras, 1(1), 109-115.

Resch, R. P. (1997). Utopia, Dystopia, and the Middle Class in George Orwell's Nineteen Eighty-Four. boundary 2, 24(1), 137-176.

Roazen, P. (1978). Orwell, Freud, and 1984. The Virginia quarterly review, 54(4), 675.

Rodden, J. (2007). The cambridge companion to george orwell: Cambridge University Press.

Sawant, N. (2012). Evolution of George Orwell as a Novelist. Journal of Literature, Culture and Media Studies, 3(5\&6), 21-30.

Schimmel, P. (2002). 'IN MY END IS MY BEGINNING': T.S. ELIOT'S THE WASTE LAND AND AFTER. British Journal of Psychotherapy, 18(3), 381-399. doi: 10.1111/j.1752-0118.2002.tb00039.x

Stape, J. H. (Ed.). (1996). The Cambridge Companion to Joseph Conrad. Cambrige: Cambridge University Press.

Stewart, R. (1981). Orwell's Waste Land. International Fiction Review, 8(2).

Tyner, J. A. (2004). Self and space, resistance and discipline: a Foucauldian reading of George Orwell's 1984. Social \& Cultural Geography, 5(1), 129-149.

Varricchio, M. (1999). Power of Images/Images of Power in Brave New World and Nineteen Eighty-Four. Utopian Studies, 10(1), 98-114.

Von Franz, M.-L. (1968). The Process of Individuation. In C. G. Jung, M. L. Von Franz, J. Jacobi \& A. Jaffe (Eds.), Man and his symbols. New York: Dell Pub. 